\title{
Probiotics in Functional Foods: Survival Assessment and Approaches for Improved Viability
}

\author{
Jeyanthi Palanivelu $^{1, *}$, Sundaram Thanigaivel ${ }^{2} \mathbb{D}$, Sundaram Vickram ${ }^{2}$, Nibedita Dey ${ }^{2} \mathbb{D}$, Dasha Mihaylova $^{3} \mathbb{D}$ \\ and Ivelina Desseva ${ }^{4, *}$ (i) \\ 1 Department of Biotechnology, Vel Tech Rangarajan Dr. Sagunthala R\&D Institute of Science and Technology, \\ Chennai 600062, India \\ 2 Department of Biotechnology, Saveetha School of Engineering, Saveetha Institute of Medical and Technical \\ Sciences, Chennai 602105, India; thanigaivels.sse@saveetha.com (S.T.); vickramas.sse@saveetha.com (S.V.); \\ nibeditadey.sse@saveetha.com (N.D.) \\ 3 Department of Biotechnology, Technological Faculty, University of Food Technologies, 4002 Plovdiv, Bulgaria; \\ dashamihaylova@yahoo.com \\ 4 Department of Analytical Chemistry and Physical Chemistry, Technological Faculty, \\ University of Food Technologies, 4002 Plovdiv, Bulgaria \\ * Correspondence: jeypalanivelu91@gmail.com (J.P.); ivelina_hristova_vn@abv.bg (I.D.)
}

check for

updates

Citation: Palanivelu, J.; Thanigaivel, S.; Vickram, S.; Dey, N.; Mihaylova,

D.; Desseva, I. Probiotics in

Functional Foods: Survival

Assessment and Approaches for Improved Viability. Appl. Sci. 2022, 12,455. https://doi.org/10.3390/ app12010455

Academic Editors: Ester Betoret and Noelia Betoret

Received: 31 August 2021 Accepted: 15 October 2021 Published: 4 January 2022

Publisher's Note: MDPI stays neutral with regard to jurisdictional claims in published maps and institutional affiliations.

Copyright: (C) 2022 by the authors. Licensee MDPI, Basel, Switzerland This article is an open access article distributed under the terms and conditions of the Creative Commons Attribution (CC BY) license (https:// creativecommons.org/licenses/by/ $4.0 /)$

\begin{abstract}
Nowadays, food is no longer just for nutrition. Consumers are more demanding and expect to get health benefits from their daily meals. Various areas of the food industry are in great demand of functional chemicals to enhance the taste and nutritional value of their products. Probiotic bacteria have already been part of the human's routine for good gut microbiota maintenance in terms of pharmaceutical products. Their incorporation in food however is a challenging task that offers great opportunities but has limitations as well. Specifically, the purpose of this review is to emphasize the importance of probiotics in food, to assess their survival through gastrointestinal tract, and to highlight the recent advances in approaches for their improved viability.
\end{abstract}

Keywords: probiotics; food; microencapsulation; viability

\section{Introduction}

Nowadays, food is no longer regarded as a nutritional portion. The general perception is that food has a direct impact on a person's health. Therefore, the consumer's requirements towards the quality of their meal already include the presence of active components that have the potential to modulate to bring benefits to the body. As a result, the key to effective marketing and adoption of innovative foods is not only the notion of food quality across the supply chain but also the addition of value-added food functionality. Therefore, foods are not simply seen as having the capability to satiate hunger, but also have the additional capability to improve physical and mental health and to keep consumers free from nutritional disorders [1-3]. Due to the increased life expectancy and rising healthcare costs associated with an ageing population, so-called functional foods are becoming increasingly popular among health-conscious people [4-6].

The word "functional" is often used to refer to food products that are believed to have particular physiological benefits that are useful to the human body in some way [7-9]. Functional foods, as opposed to pills or capsules, must demonstrate their health benefits when consumed as a part of a balanced diet. Yet, there is no universally agreed definition of what constitutes a functional food. Furthermore, there is no formal definition for this phrase, and in most countries, there is a distinction between conventional and functional foods [9-12]. Some functional foods are made by altering processing methods or adding chemicals to foods. When it comes to bioactive components, the features of a product can be custom-tailored to treat an illness or help enhance general health. The functional ingredient in foods could come from the addition of different phytochemicals, such as antioxidants, 
vitamins, fibers, minerals, omega-3-fatty acids, etc. It could be, also, live cells of "good" microorganisms. The latter are called probiotics. They are more precisely described as live bacteria that, when supplied in sufficient proportions, can provide health advantages by maintaining the balance of microorganisms in the human gastrointestinal tract (GIT), preventing various diseases, and boosting the host immune system [13]. However, the quality of most commercial probiotic meals is variable in terms of live probiotic count and often does not satisfy their label claims for strain type. When probiotic microorganisms are swallowed, they provide a health benefit to the host, albeit the advantages vary depending on the species or strain. The majority of the benefits linked to probiotics are related to the preservation of normal intestinal flora, demonstrating the ability to live through the upper gastrointestinal system as well as the ability to survive and develop in the intestinal region [14].

The growing application of microorganisms in food formulations requires the adoption of uniform criteria for their classification as probiotics. A general terminology consensus between science, food producers, regulators, and consumers is needed. In order to consider a given strain as a probiotic, several steps should be carried out [15]. The candidate should be fully characterized and safe for human consumption. It must possess at least one proven beneficial effect for the human body, and must remain alive through product manufacturing and storage [15]. The European Food Safety Authority (EFSA) has maintained a list of species presumed to be safe for human consumption in foods under the "Qualified Presumption of Safety" (QPS) concept since 2007 [16]. In Europe, if a strain does not belong to a QPS species then it must follow the Novel Food regulation before being brought to market [16]. The U.S. Food and Drug Administration adopted the term "generally recognized as safe" (GRAS). A substance may be GRAS only if its general recognition of safety is based on the views of experts qualified to evaluate the safety of the substance [17]. With regard to encapsulated probiotics in the food industry, it should be noted that only approved for human consumption encapsulating materials are allowed to be used [18].

The most studied and implemented probiotic microorganisms belong to the group of lactic acid bacteria, bifidobacteria, and yeasts [19]. Strains of Streptococcus and Enterococcus are also in use. Probiotics have been implemented in a wide range of food products, including dairy products, meat, beverages, cereals, vegetables, and fruits, as well as bread goods $[20,21]$. The effective functioning of probiotics, however, is greatly dependent on their viability and activity, and these need to be maintained at high levels [22]. When probiotics are subjected to harsh environmental conditions, like food processing and storage, their viability is greatly diminished [23-25]. At the same time, the safety profile with the use of live microorganisms is still a sensitive matter and no agreement exists [25]. More reliable in vivo studies are needed in this regard. So far, studies have demonstrated good strain-specific correlation between in vitro and in vivo assays in prediction of the immunomodulatory properties of lactic acid bacteria [26,27]. Nevertheless, in parallel, studies on how to keep the cells alive through the gastrointestinal tract are required.

The search for appropriate methods for protecting probiotic cells has led to the development of many technologies, and microencapsulation is the most significant one. The process of probiotic microencapsulation has been reported in several studies and it gained much attention in the encapsulation techniques using a variety of processes, including emulsification, extrusion, and spray drying [28-31]. However, a careful assessment of the effects of all chemicals and conditions on the probiotic bacteria is required.

This review attempts to present a more contemporary scientific and technical evaluation of probiotics as functional foods. In particular, the review focuses on probiotics' improved qualities and their capacity to keep longer under encapsulated and unencapsulated probiotic products. Furthermore, a comprehensive analysis of food matrix features and probiotic bacteria, as well as their viability, survival, and viability enhancement will be conducted. 


\section{Probiotics in Food Products}

Foods having functional qualities, particularly those containing bioactive chemicals or containing probiotics, have been developed in response to the increased need for a more nutritious diet. When probiotics are consumed in sufficient quantities, they provide health benefits to the individual ingesting them [32]. Many beneficial effects of these microbes have been discovered, most of which are related to gastrointestinal health and the immune system, but also to diabetes, obesity, and hypercholesterolemia as well as cancer, to name a few examples [33]. Several sectors of the food industry and researchers have all become interested in the global probiotic market, with the main focus being on developing novel probiotic-rich food products and conducting in-depth research on specific probiotic properties and their impact on human health [34]. Although the aforementioned has almost the statute of postulate, the official report of the American Gastroenterological Association on the role of probiotics in the management of gastrointestinal disorders identified that significant knowledge gaps exist [14].

In order to receive health benefits associated with probiotics, the viability of probiotics in food is required. In most cases, only animal or clinical research can be used to determine whether or not probiotic cultures are beneficial to the host's health. As a result, the viability test for probiotics is the most feasible quality assurance test $[35,36]$. The presence of probiotics in excess of viable cells per day has typically been linked to health benefits in clinical research. A recent study discussed how food supplements including probiotics could meet present technological hurdles and meet enhanced functionality and sensory acceptances while looking ahead to upcoming developments [32,37]. In Figure 1, the basic criteria for selecting suitable probiotic strains for specific applications are shown. These are functional, safety, technological and physiological criteria. The main sources can be from probiotic or symbiotic products or from intestinal origin.

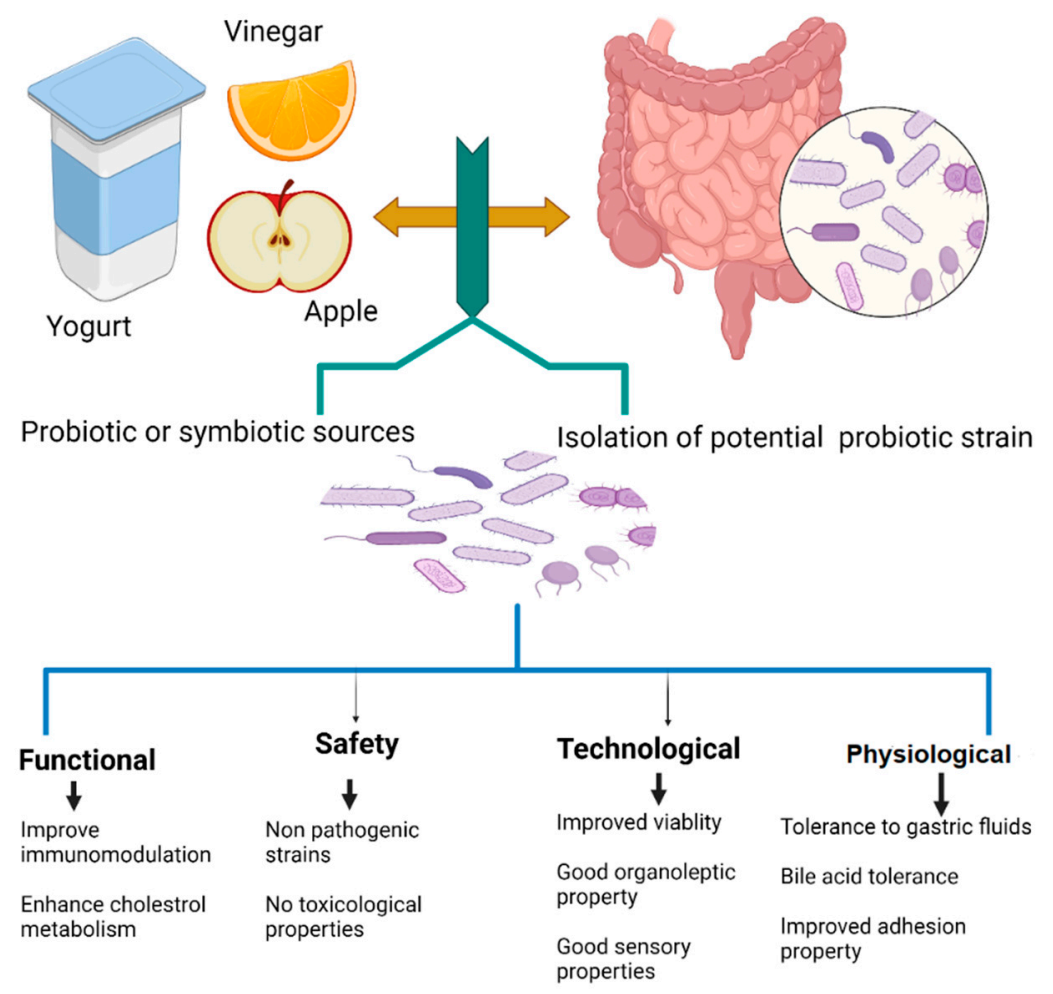

Figure 1. Basic criteria for selecting suitable probiotic strain for specific applications.

\subsection{Selection and Identification of Probiotic Strains}

Isolating, evaluating, and characterizing new probiotic candidates require a holistic, multi-step approach. The main selection criteria for probiotics are based on many functional properties, such as tolerance to gastric acidity, bile and phenol toxicity, and the ability 
to deconjugate bile salts [38]. In addition, new probiotics should be selected based on the strain's characteristics. Therefore, new methods are needed to select and characterize probiotic strains. In this regard, molecular techniques are of particular importance [39]. Bioactive produced by probiotics could help to prevent spoilage of food, increase nutritional value, improve aroma and sensory qualities, and detoxify foods. When it comes to bioactive synthesis, there are differences between species and strains [40]. The synthesis of exopolysaccharides (EPS) or bile salt hydrolase (BSH), for example, differs significantly between species and within strains within a given species. With available outcomes, it is impossible to assume that all lactobacilli, or even all strains of a given species, generate the same amount of a given metabolite. The foremost step in assuring functionality is to define it [32].

\subsection{Functionality of Probiotics}

Many scientific reports demonstrate the positive effects for the intestinal tract of inactivated probiotic cells. In their review, Piqué et al. [25] gathered recent studies of the use of heat-treated probiotic cells, cell-free supernatants, or purified key components as a provider of mainly immunomodulatory effects, protection against enteropathogens, and maintenance of intestinal barrier integrity.

Apart from the ongoing debate over whether live probiotics are ultimately completely safe to consume, most scientific reports continue to study the positive effects of viable probiotic cells in the GIT. So far, the main focus has been on the direct outcomes of gastrointestinal disorders. Lactobacillus rhamnosus is frequently reported to reduce the risk of antibiotic-associated diarrhea in children [41,42]. The strains Lactobacillus bulgaricus, Lactobacillus plantarum, and Streptococcus thermophilus exerted significant anti-inflammatory potential [43,44]. Moreover, a meta-analysis on the use of probiotic bacteria in cancer patients undergoing chemotherapy and radiation therapy revealed encouraging results about the prevention of radiation-induced diarrhea [45,46]. Many studies focus on the possible beneficial effect of probiotic administration and autism spectrum disorder [47], cardiometabolic disorders and chronic kidney disease [48], skin disorder management [49]. Preliminary findings on the relationship between probiotics and cognitive and behavioral processes (neurological, metabolic, hormonal and immunological signaling pathways) arise the hope of new application for these microorganisms to serve as psychobiotics [50].

\subsection{Survival Assessment and Viability}

When discussing the survival of probiotics two aspects should be considered. The first one is whether the selective strains are initially able to survive through the gastrointestinal tract and then, do they remain viable through the food manufacturing process. Most of the commercially implemented probiotics were isolated from milk and dairy products, so it is not surprising that these products are today considered the main functional food [51]. The low gastric $\mathrm{pH}$ tolerance and high bile salt concentrations are the most important criteria for the selection of the probiotic strains [52]. On the other hand, the choice of food matrix and further processing conditions are crucial for their survival. It is also critical to ensure that probiotic food products contain the minimum recommended level of probiotics $\left(10^{6}-10^{7} \mathrm{CFU} / \mathrm{mL}\right.$ product [53]) in the final product. This level of probiotics should be maintained throughout the product's shelf life because the number of viable and active probiotic cells per gram or milliliter of probiotic food products at the time of consumption determines their health effects [54]. Therefore, probiotics must meet severe technological standards in order to remain active throughout the entire manufacturing and storage process. So far, representatives of genera Lactobacillus and Bifidobacterium have long records in food implementation [55-57] because they are considered GRAS.

During the manufacturing or storage process, the number of active probiotic bacteria declines by a fold factor of 10-100 or more. All of the factors that influence probiotics' longterm survival in meals include oxygen content, heating temperature, acidity, water activity, osmotic stress, moisture content, and packing material [40]. The number of viable and 
active cells per gram or milliliter of probiotic food products at the moment of consumption is the most critical value for the functional food, as it determines their efficacy [58]. Two general approaches exist in order to assess the vitality of individual bacterial cells in foods [59]. The golden standard remains the culture-dependent method for determination of numbers of colony-forming units per gram of original material $(\mathrm{cfu} / \mathrm{g})$ [60]. On the other hand DNA and flow cytometric-based methods are constantly improved in order to obtain culture-independent and reliable screening methods [59].

Figure 2 summarizes the main factors that influence the viability of probiotics during manufacturing and consumption. During processing, the food component interactions as sugars, salt, antimicrobial substances can significantly affect the viability of probiotics. Together with the moisture content and acidity, these are the main requirements. Processing factors are also critical because they include often various mechanical forces are applied and most frequently different temperature regimes. The latter is one of the very limiting factors for the survival of probiotic bacteria. During storage, again the moisture content and acidity play an important role, as well as the type of packaging material [61]. Once the functional food is consumed then the environmental factors of different compartments of the GIT are applied.

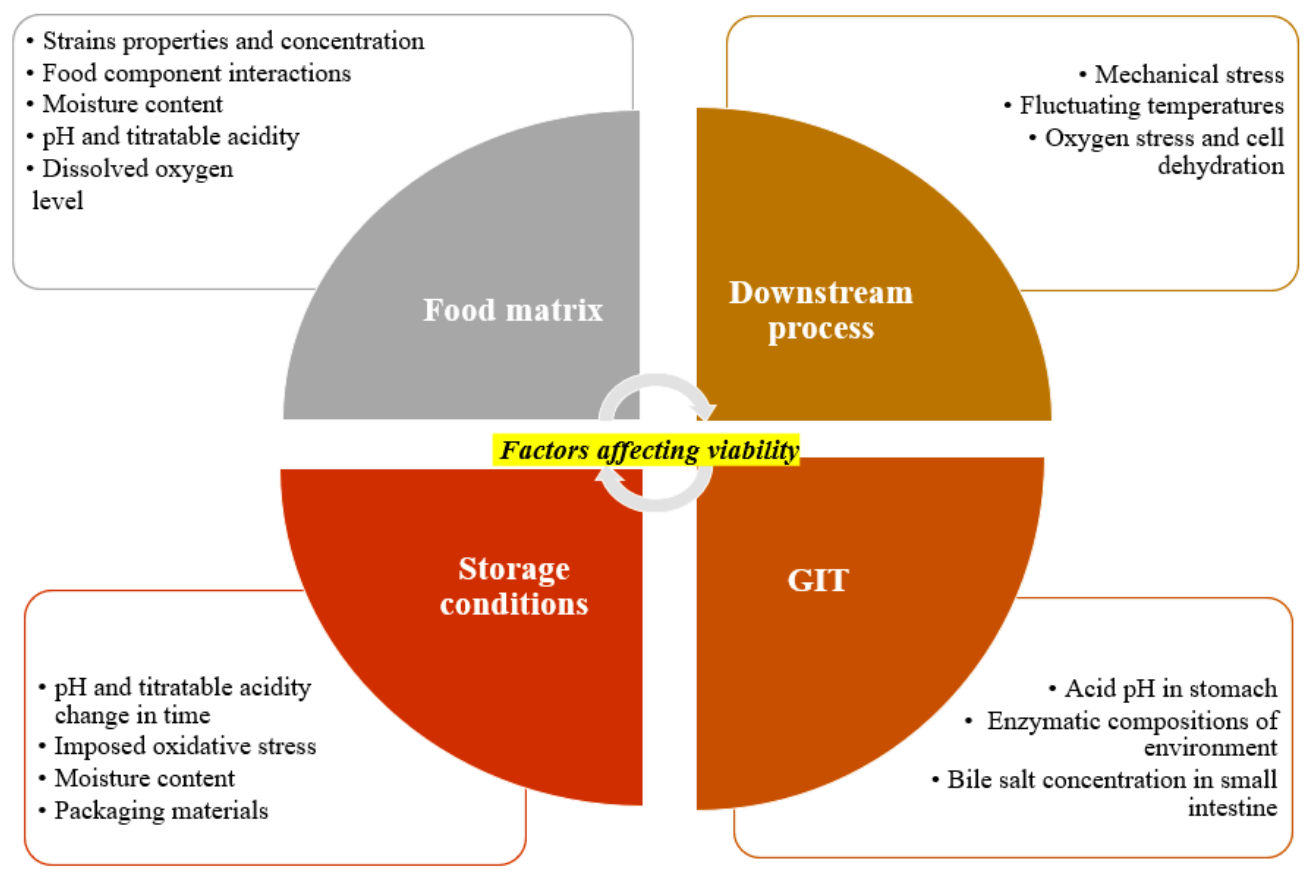

Figure 2. Factors influencing viability of probiotics [62].

\subsection{Role of Food Ingredients and Additives}

The compatibility of probiotic bacteria with dietary items has a significant impact on their development and survivability. Beneficial, neutral, or detrimental effects on probiotics may be seen with respect to the components [63]. Furthermore, food additives such as salts, sugars, sweeteners, aroma compounds, preservatives greatly influence probiotic survival [64]. Lactic acid bacteria strains were proved to interact with aroma compounds involved in cheese production and thus modulate the flavor of the product [65]. Food components and chemicals that interact with probiotics may have a negative impact on their ability to develop and survive. For example, an important group of bioactive compounds is polyphenolic compounds that are abundant in plant-derived food. They possess antioxidant properties and are generally associated with health benefits. Studies demonstrate, however, that they inhibit the growth of lactic acid bacteria [66].

There is a group of compounds that were proved to enhance the growth of probiotic cultures. They are called prebiotics and are defined as 'a substrate that is selectively utilized 
by host microorganisms conferring a health benefit' [67]. These are food components that are not digested by the body but are metabolized by probiotic bacteria. It is believed that probiotics grow poorly or do not develop in diets other than fermented milk products because they do not have sufficient proteolytic and glycolytic activity, as well as a high requirement for certain nutrients such as non-protein nitrogen and B-group vitamins [68]. A good example of prebiotic compounds that stimulate the growth of lactobacilli and bifidobacteria are oligosaccharides [69]. In Table 1, the effect of prebiotics on the viability of probiotics is shown.

Table 1. Effect of prebiotics on viability of probiotics.

\begin{tabular}{|c|c|c|c|}
\hline Name of Probiotic & Effect of Prebiotic & Probiotics Survival & References \\
\hline Bifidobacterium species & Fructo and galacto oligosaccharides & $\begin{array}{l}\text { Enhanced viability was observed upon the } \\
\text { dosage level of prebiotics }\end{array}$ & {$[70]$} \\
\hline $\begin{array}{l}\text { Bifidobacterium infantis, } B \text {. } \\
\text { pseudolongum, B. animalis } \\
\quad \text { and B. longum }\end{array}$ & Lactulose, raftilose, maize, and insulin & $\begin{array}{l}\text { Retentive viability was observed up to } 28 \\
\text { days with prebiotics addition }\end{array}$ & {$[3]$} \\
\hline B. animalis and B. longum & Fructo oligosaccharide & $\begin{array}{c}\text { The recommended level of viability was } \\
\text { not achieved }\end{array}$ & {$[2]$} \\
\hline $\begin{array}{l}\text { Lactobacillus casei, L. zeae } \\
\text { L. paracasei, L. rhamnosus }\end{array}$ & Lactulose, raftilose, Maize and insulin & Strain specific survival was observed & {$[71]$} \\
\hline L. rhamnosus & $\begin{array}{l}\text { Oligofructose and polydextrose } \\
\text { mediated prebiotic substances }\end{array}$ & $\begin{array}{l}\text { Resulted in a high rate of probiotic } \\
\text { survival when substituted with prebiotics }\end{array}$ & {$[72]$} \\
\hline L. acidophilus & Short and long chain inulin & $\begin{array}{l}\text { Viable count was increased with } L \text {. } \\
\text { acidophilus with addition of prebiotics }\end{array}$ & {$[73]$} \\
\hline L. casei,L. acidophilus & Inulin and maize & $\begin{array}{l}\text { The viability of probiotics has been } \\
\text { improved with supplementation of yogurt }\end{array}$ & [35] \\
\hline B. animalis & $\begin{array}{l}\text { Beta glucan from two different } \\
\text { cereals sources }\end{array}$ & $\begin{array}{l}\text { Viability and stability were improved with } \\
\text { yogurt supplementation. } \\
\text { Improved viability in the ice cream mix }\end{array}$ & {$[74]$} \\
\hline L. acidophilus, B.animalis & Inulin and oligo fructose & $\begin{array}{l}\text { with minimum of } 10^{6} \text { of } B \text {. animalis colony } \\
\text { forming units of was maintained }\end{array}$ & {$[62]$} \\
\hline L. rhamnosus & $\begin{array}{c}\text { Combination of inulin mixed with } \\
\text { yeast extract }\end{array}$ & $\begin{array}{l}\text { The combined mixture positively } \\
\text { influences on the growth of L. reuteri }\end{array}$ & {$[8]$} \\
\hline
\end{tabular}

\section{Progress to Enhance Viability}

The viability of probiotics has been increased by the use of a number of different ways. A significant challenge for the food business is the utilization of these functional ingredients to generate stable items with active properties that remain active during manufacturing and storage till consumption [8]. Encapsulation is a process in which an active chemical is imprisoned by a wall material that is either on the nanoscale, micrometer scale, or millimeter scale in size. Micro- and nano-encapsulation are rapidly becoming available to solve potential bioavailability issues, giving unique solutions to the food industry's difficulties in the process [11]. Generally speaking, microparticles are colloidal particles with dimensions ranging from 3 to $800 \mathrm{~nm}$, and nanoparticles are colloidal particles with diameters ranging from 10 to $1000 \mathrm{~nm}$ [75].

Encapsulating probiotic cells in small sealed capsules to isolate them from their environment is known as microencapsulation of probiotic cells (also known as probiotic cell encapsulation). The capsules release their contents at a controlled rate over a long period of time under the influence of various processing and environmental variables in the gut media [8,76]. It looks to be the most effective method of protecting oneself against microbes on the market. Probiotic microencapsulation, however, is a time-consuming process. For microencapsulating probiotics or other beneficial compounds, a number of different techniques have been developed. The bulk of these procedures entail encasing probiotics in polymers such as starch, alginate, and carrageenan, coatings of them in emulsions, or prebiotics with dry impacting and enteric coatings on the surface of food products $[10,11]$. The encapsulation techniques that include drying of probiotics are well studied and applied. It includes spray-drying, freeze-drying, and vacuum-drying [77]. Gel microspheres are also used. Electrospinning is a promising approach that allows 
encapsulation at the nano level under mild conditions [78]. Table 2 summarizes the recent progress in encapsulating probiotics to increase their viability.

Table 2. Recent techniques used to enhance viability of probiotics for commercial applications.

\begin{tabular}{|c|c|c|c|c|c|c|c|}
\hline Techniques & Probiotic & Size Range & Shape & Conditions & Remarks & $\begin{array}{c}\text { Efficiency of } \\
\text { Encapsulation }\end{array}$ & References \\
\hline Freeze drying & $\begin{array}{l}\text { L. plantarum } \\
\text { P. acidilactici } \\
\text { Pediococcus } \\
\text { pentosaceus } \\
\text { S. boulardii } \\
\text { L. acidophilus } \\
\text { L. casei } \\
\text { L. rhamnosus } \\
\text { P. acidilactici }\end{array}$ & $>1 \mathrm{~mm}$ & Irregular & $\begin{array}{l}\text { Vacuum }-0.5 \\
\text { torr, lower } \\
\text { condensation } \\
\text { temperature } \\
\text { preferred }\end{array}$ & $\begin{array}{c}\text { Porous } \\
\text { structure, } \\
\text { expensive, }\end{array}$ & $\begin{array}{c}98 \% \\
\text { (approximate } \\
\text { maximum) }\end{array}$ & [79-90] \\
\hline Extrusion & $\begin{array}{l}\text { L. acidophilus } \\
\text { Lactiplantibacillus } \\
\text { plantarum } \\
\text { Lacticaseibacillus } \\
\text { paracasei } \\
\text { Lactiplantibacillus } \\
\text { pentosus } \\
\text { L. casei }\end{array}$ & $3 \mathrm{~mm}$ & Beaded & Gelling $0.25 \%$ & $\begin{array}{l}\text { Simple, cost } \\
\text { effective, better } \\
\text { viability, } \\
\text { difficulty in } \\
\text { scaling up }\end{array}$ & $\begin{array}{l}97 \% \\
\text { (approximate } \\
\text { maximum) }\end{array}$ & [91-96] \\
\hline Emulsion & $\begin{array}{l}\text { L. acidophilus } \\
\text { L. plantarum } \\
\text { L. casei } \\
\text { Enterococcus } \\
\text { faecium } \\
\text { S. boulardii } \\
\text { L. salivarius } \\
\text { Bifidobacterium }\end{array}$ & $2 \mathrm{~mm}$ & Spherical & $\begin{array}{l}\text { Speed of } \\
\text { agitation } \\
\text { should be } \\
\text { controlled } \\
\text { along with } \\
\text { other general } \\
\text { reaction } \\
\text { parameters }\end{array}$ & $\begin{array}{c}\text { High survival, } \\
1 \text { mm capsules } \\
\text { produced }\end{array}$ & $\begin{array}{c}84-97 \% \\
\text { (approximate } \\
\text { maximum) }\end{array}$ & [96-102] \\
\hline Spray drying & $\begin{array}{l}\text { L. plantarum } \\
\text { L. paracasei } \\
\text { S. cerevisiae }\end{array}$ & $80 \mathrm{~mm}$ & Spherical & $\begin{array}{l}\text { Nozzle } \\
\text { determines the } \\
\text { shape and } \\
\text { concentration }\end{array}$ & $\begin{array}{l}\text { Improved } \\
\text { yield, low } \\
\text { density } \\
\text { particles }\end{array}$ & $\begin{array}{c}96 \% \\
\text { (approximate } \\
\text { maximum) }\end{array}$ & {$[92,103-107]$} \\
\hline Refractance drying & L. plantarum & $\begin{array}{l}\text { Greater than } \\
1 \mathrm{~mm}\end{array}$ & Flaky & $\begin{array}{c}\text { Temperature } \\
60 \text { degree } \\
\text { Celsius }\end{array}$ & $\begin{array}{l}\text { Good quality, } \\
\text { simple cost } \\
\text { effective, better } \\
\text { viability }\end{array}$ & $\begin{array}{c}93 \% \\
\text { (approximate } \\
\text { maximum) }\end{array}$ & [107-110] \\
\hline Electrohydrodynamic & $\begin{array}{l}\text { L. plantarum } \\
\text { B. lactis } \\
\text { L. gasseri } \\
\text { Bifidobacterium } \\
\text { L. rhamnosus } \\
\text { B. animalis } \\
\text { lactis BB12 } \\
\text { Streptococcus } \\
\text { thermophilus }\end{array}$ & $150 \mathrm{~nm}$ & Fibers & $\begin{array}{l}\text { Voltage and tip } \\
\text { resistance }\end{array}$ & $\begin{array}{l}\text { Reproducible } \\
\text { fibers, good } \\
\text { yield }\end{array}$ & $\begin{array}{c}90 \% \\
\text { (approximate } \\
\text { maximum) }\end{array}$ & {$[90,111-114]$} \\
\hline $\begin{array}{l}\text { Three-dimensional } \\
\text { printing }\end{array}$ & $\begin{array}{l}\text { mashed } \\
\text { potatoes } \\
\text { probiotics }\end{array}$ & - & Fibers & $\begin{array}{l}\text { Nozzle } \\
\text { diameter }\end{array}$ & Good viability & - & {$[115,116]$} \\
\hline Microfluidics & gut bacteria & - & Droplet & $\begin{array}{l}\text { Double } \\
\text { emulsion }\end{array}$ & $\begin{array}{l}\text { Deep function- } \\
\text { alization of } \\
\text { carriers and } \\
\text { profiling of } \\
\text { probiotics }\end{array}$ & - & {$[117,118]$} \\
\hline
\end{tabular}

\section{Limitations and Future Perspectives}

As many novel and alternative approaches have been employed to increase the shelf life of probiotics, many regulatory issues have been arising during storage conditions. Refrigeration is still an inevitable procedure that needs to be followed even after processing probiotics. Humid conditions cause degradation in the probiotic metabolically and texturally. Acid stress in citrus and foods with lower $\mathrm{pH}$ requires mandatory refrigeration to avoid deactivation and oxidation of the bioactive foods. Although many techniques arise to upgrade the shelf life of probiotics, the need to maintain ambient conditions makes the overall process very expensive and cumbersome [8]. 
The process of microencapsulation enhances and stabilizes sensory properties, as well as immobilizing cells to ensure uniform distribution of the product throughout the product's whole surface. There are a variety of elements that influence the efficiency of microencapsulation. When it comes to viability, the type of microencapsulation used by the method of spray drying, the intake and output temperatures, as well as the probiotic strains chosen, are all important considerations to consider in future prospects [12]. It is particularly important to choose the right wall material for the probiotics since they must be protected from oxygen, heat and other environmental challenges during drying, processing, and storage, as well as from low $\mathrm{pH}$ and protease in the gastric tract [12].

Presently, there are two important areas of interest are being investigated with the goal of enhancing the probiotic potential of traditional Cell culture cereal-based beverages: the development of stress-tolerant starters with established probiotic properties and the maintenance of probiotic characteristics both at the point of consumption and throughout the gastrointestinal tract to the site of action in the colon, for processing of microencapsulation, protein-carbohydrate oil emulsions-based materials are preferred over other materials such as cellulose acetate phthalate, xanthan gum, gellan gum, and starch alginate because they produce smaller beads and have no effect on the sensory attributes of the product [75].

In addition, greater research is needed into the use of probiotics in conjunction with legume supplementation/enrichment of cereal-based beverages to counteract the widespread protein-energy malnutrition that exists in poor nations. Ogi, for example, is made from maize, which has low levels of the amino acids lysine and tryptophan. The addition of a legume protein, such as soybeans or other readily available legumes, is currently standard practice ensuring amino acid complementarities in the diet. Understanding how legume inclusion in cereal-based beverages impacts their ability to maintain probiotics and consumer acceptance is critical to the development of new products [76].

\section{Conclusions}

Probiotics in food must remain viable over the entire shelf life of the food product. It is vital to select the most appropriate strain-food matrix combination, as well as to provide convenient packing and storage conditions. In order to ensure effective probiotic survival for health benefit purposes, it is important that the strains used, feeding matrix, production phases, and storage conditions be compatible with each other. Including prebiotics, growth factors/promoters, fruit and plant products in the food matrix, as well as providing proper processing, fermentation, and storage conditions, all aid in the survival of probiotic bacteria. It is necessary to create an appropriate processing and storage environment with low oxygen and water content, minimal osmotic stress, and suitable packing in order to obtain the best results. Besides being beneficial to the gastrointestinal system, microencapsulation has shown to be a viable method of overcoming the problem of low probiotic microbial stability in the food matrix. As a result, the food industry should employ microencapsulation to improve the effectiveness of preventive measures.

When it comes to protecting a functional element, encapsulation is an excellent choice. It has a plethora of advantages. There are a variety of approaches that can be used to encapsulate the functional components. The maximum encapsulation efficiency has been around $98 \%$ by traditional freeze-drying techniques. The use of spray drying or other newer alternatives still has a long way to go to attain the efficiency at par with freeze drying. By encapsulating functional components, it is possible to establish a controlled release of the active medicine. Encapsulation can be used to create fortifying meals that provide specific health benefits while also providing the functionality that is required. It has the potential to alleviate micronutrient shortages around the world. One of the most pressing issues that have to be addressed in future research is the transfer of the laboratory-scale encapsulating technology to an industrial scale. 
Author Contributions: Conceptualization, I.D., J.P. and D.M.; writing—original draft preparation, J.P., I.D., D.M., S.T., S.V. and N.D.; writing-review and editing, J.P., S.T., S.V., N.D., I.D. and D.M.; visualization, J.P.; supervision, I.D. All authors have read and agreed to the published version of the manuscript.

Funding: This research received no external funding.

Institutional Review Board Statement: Not applicable.

Informed Consent Statement: Not applicable.

Data Availability Statement: Not applicable.

Conflicts of Interest: The authors declare no conflict of interest.

\section{References}

1. Saguy, I.S.; Sirotinskaya, V. Challenges in exploiting open innovation's full potential in the food industry with a focus on small and medium enterprises (SMEs). Trends Food Sci. Technol. 2014, 38, 136-148. [CrossRef]

2. Savino, T.; Testa, S.; Messeni Petruzzelli, A. Researcher understanding of food innovations in Nordic and Southern European countries: A systematic literature review. Trends Food Sci. Technol. 2018, 77, 54-63. [CrossRef]

3. Martin-Rios, C.; Demen-Meier, C.; Gössling, S.; Cornuz, C. Food waste management innovations in the foodservice industry. Waste Manag. 2018, 79, 196-206. [CrossRef] [PubMed]

4. Lenssen, K.; Bast, A.; de Boer, A. Should botanical health claims be substantiated with evidence on traditional use? Reviewing the stakeholders' arguments. PharmaNutrition 2020, 14, 100232. [CrossRef]

5. Dinicola, S.; Proietti, S.; Cucina, A.; Bizzarri, M.; Fuso, A. Alpha-Lipoic Acid Downregulates IL-1 $\beta$ and IL-6 by DNA Hypermethylation in SK-N-BE Neuroblastoma Cells. Antioxidants 2017, 6, 74. [CrossRef] [PubMed]

6. Li, H.; Inoue, A.; Taniguchi, S.; Yukutake, T.; Suyama, K.; Nose, T.; Maeda, I. Multifunctional biological activities of water extract of housefly larvae (Musca domestica). PharmaNutrition 2017, 5, 119-126. [CrossRef]

7. Feng, K.; Zhai, M.-Y.; Zhang, Y.; Linhardt, R.J.; Zong, M.-H.; Li, L.; Wu, H. Improved Viability and Thermal Stability of the Probiotics Encapsulated in a Novel Electrospun Fiber Mat. J. Agric. Food Chem. 2018, 66, 10890-10897. [CrossRef]

8. Yoha, K.S.; Nida, S.; Dutta, S.; Moses, J.A.; Anandharamakrishnan, C. Targeted Delivery of Probiotics: Perspectives on Research and Commercialization. Probiotics Antimicrob. Proteins 2021, 1-34. [CrossRef] [PubMed]

9. Dinkçi, N.; Akdeniz, V.; Akalin, A.S. Survival of probiotics in functional foods during shelf life. In Food Quality and Shelf Life; Galanakis, C.M., Ed.; Elsevier: Amsterdam, The Netherlands, 2019; pp. 201-233, ISBN 978-0-12-817190-5.

10. Chandrashekhar, P.; Minooei, F.; Arreguin, W.; Masigol, M.; Steinbach-Rankins, J.M. Perspectives on Existing and Novel Alternative Intravaginal Probiotic Delivery Methods in the Context of Bacterial Vaginosis Infection. AAPS J. 2021, 23, 66. [CrossRef]

11. Mojaveri, S.J.; Hosseini, S.F.; Gharsallaoui, A. Viability improvement of Bifidobacterium animalis Bb12 by encapsulation in chitosan/poly(vinyl alcohol) hybrid electrospun fiber mats. Carbohydr. Polym. 2020, 241, 116278. [CrossRef] [PubMed]

12. Feng, K.; Huang, R.-M.; Wu, R.-Q.; Wei, Y.-S.; Zong, M.-H.; Linhardt, R.J.; Wu, H. A novel route for double-layered encapsulation of probiotics with improved viability under adverse conditions. Food Chem. 2020, 310, 125977. [CrossRef] [PubMed]

13. Mc Carthy, U.; Uysal, I.; Badia-Melis, R.; Mercier, S.; O’Donnell, C.; Ktenioudaki, A. Global food security-Issues, challenges and technological solutions. Trends Food Sci. Technol. 2018, 77, 11-20. [CrossRef]

14. Su, G.L.; Ko, C.W.; Bercik, P.; Falck-Ytter, Y.; Sultan, S.; Weizman, A.V.; Morgan, R.L. AGA Clinical Practice Guidelines on the Role of Probiotics in the Management of Gastrointestinal Disorders. Gastroenterology 2020, 159, 697-705. [CrossRef] [PubMed]

15. Binda, S.; Hill, C.; Johansen, E.; Obis, D.; Pot, B.; Sanders, M.E.; Tremblay, A.; Ouwehand, A.C. Criteria to Qualify Microorganisms as "Probiotic" in Foods and Dietary Supplements. Front. Microbiol. 2020, 11, 1662. [CrossRef]

16. Barlow, S.; Chesson, A.; Collins, J.D.; Dybing, E.; Flynn, A.; Fruijtier-, C.; Hardy, A.; Knaap, A.; Kuiper, H.; Neindre, P.L.; et al. Introduction of a Qualified Presumption of Safety (QPS) approach for assessment of selected microorganisms referred to EFSA-Opinion of the Scientific Committee. EFSA J. 2007, 5, 587. [CrossRef]

17. Burdock, G.A.; Carabin, I.G. Generally recognized as safe (GRAS): History and description. Toxicol. Lett. 2004, 150, 3-18. [CrossRef] [PubMed]

18. Arenas-Jal, M.; Suñé-Negre, J.M.; García-Montoya, E. An overview of microencapsulation in the food industry: Opportunities, challenges, and innovations. Eur. Food Res. Technol. 2020, 246, 1371-1382. [CrossRef]

19. Teneva-Angelova, T.; Hristova, I.; Pavlov, A.; Beshkova, D. Chapter 4-Lactic Acid Bacteria-From Nature Through Food to Health. In Handbook of Food Bioengineering; Grumezescu, A., Holban, A.M., Eds.; Academic Press: Cambridge, MA, USA, 2018; pp. 91-133, ISBN 978-0-12-811443-8.

20. Aspri, M.; Papademas, P.; Tsaltas, D. Review on Non-Dairy Probiotics and Their Use in Non-Dairy Based Products. Fermentation 2020, 6, 30. [CrossRef]

21. Vijaya Kumar, B.; Vijayendra, S.V.N.; Reddy, O.V.S. Trends in dairy and non-dairy probiotic products-A review. J. Food Sci. Technol. 2015, 52, 6112-6124. [CrossRef] [PubMed] 
22. Calinoiu, L.F.; Vodnar, D.; Precup, G. A Review: The Probiotic Bacteria Viability under Different Conditions. Bull. UASVM Food Sci. Technol. 2016, 73, 55-60. [CrossRef]

23. Akalın, A.S.; Kesenkas, H.; Dinkci, N.; Unal, G.; Ozer, E.; Kınık, O. Enrichment of probiotic ice cream with different dietary fibers: Structural characteristics and culture viability. J. Dairy Sci. 2018, 101, 37-46. [CrossRef] [PubMed]

24. Akalın, A.S.; Karagözlü, C.; Ünal, G. Rheological properties of reduced-fat and low-fat ice cream containing whey protein isolate and inulin. Eur. Food Res. Technol. 2008, 227, 889-895. [CrossRef]

25. Piqué, N.; Berlanga, M.; Miñana-Galbis, D. Health Benefits of Heat-Killed (Tyndallized) Probiotics: An Overview. Int. J. Mol. Sci. 2019, 20, 2534. [CrossRef] [PubMed]

26. Foligne, B.; Nutten, S.; Grangette, C.; Dennin, V.; Goudercourt, D.; Poiret, S.; Dewulf, J.; Brassart, D.; Mercenier, A.; Pot, B. Correlation between in vitro and in vivo immunomodulatory properties of lactic acid bacteria. World J. Gastroenterol. 2007, 13, 236-243. [CrossRef] [PubMed]

27. Grangette, C.; Nutten, S.; Palumbo, E.; Morath, S.; Hermann, C.; Dewulf, J.; Pot, B.; Hartung, T.; Hols, P.; Mercenier, A. Enhanced antiinflammatory capacity of a Lactobacillus plantarum mutant synthesizing modified teichoic acids. Proc. Natl. Acad. Sci. USA 2005, 102, 10321-10326. [CrossRef]

28. Speranza, B.; Campaniello, D.; Petruzzi, L.; Altieri, C.; Sinigaglia, M.; Bevilacqua, A.; Rosaria Corbo, M. The Inoculation of Probiotics In Vivo Is a Challenge: Strategies to Improve Their Survival, to Avoid Unpleasant Changes, or to Enhance Their Performances in Beverages. Beverages 2020, 6, 20. [CrossRef]

29. Heidebach, T.; Först, P.; Kulozik, U. Microencapsulation of Probiotic Cells for Food Applications. Crit. Rev. Food Sci. Nutr. 2012, 52, 291-311. [CrossRef] [PubMed]

30. Yao, M.; Xie, J.; Du, H.; McClements, D.J.; Xiao, H.; Li, L. Progress in microencapsulation of probiotics: A review. Compr. Rev. Food Sci. Food Saf. 2020, 19, 857-874. [CrossRef] [PubMed]

31. Malmo, C.; Giordano, I.; Mauriello, G. Effect of Microencapsulation on Survival at Simulated Gastrointestinal Conditions and Heat Treatment of a Non Probiotic Strain, Lactiplantibacillus plantarum 48M, and the Probiotic Strain Limosilactobacillus reuteri DSM 17938. Foods 2021, 10, 217. [CrossRef]

32. Heller, K.J. Probiotic bacteria in fermented foods: Product characteristics and starter organisms. Am. J. Clin. Nutr. 2001, 73, 374S-379S. [CrossRef] [PubMed]

33. Abenavoli, L.; Scarpellini, E.; Colica, C.; Boccuto, L.; Salehi, B.; Sharifi-Rad, J.; Aiello, V.; Romano, B.; De Lorenzo, A.; Izzo, A.A.; et al. Gut Microbiota and Obesity: A Role for Probiotics. Nutrients 2019, 11, 2690. [CrossRef] [PubMed]

34. Gupta, S.; Abu-Ghannam, N. Probiotic fermentation of plant based products: Possibilities and opportunities. Crit. Rev. Food Sci. Nutr. 2012, 52, 183-199. [CrossRef] [PubMed]

35. Siciliano, R.A.; Reale, A.; Mazzeo, M.F.; Morandi, S.; Silvetti, T.; Brasca, M. Paraprobiotics: A New Perspective for Functional Foods and Nutraceuticals. Nutrients 2021, 13, 1225. [CrossRef] [PubMed]

36. Ozyurt, V.H.; Ötles, S. Properties of probiotics and encapsulated probiotics in food. Acta Sci. Pol. Technol. Aliment. 2014, 13, 413-424. [CrossRef]

37. Buriti, F.C.A.; Saad, S.M.I. Chilled milk-based desserts as emerging probiotic and prebiotic products. Crit. Rev. Food Sci. Nutr. 2014, 54, 139-150. [CrossRef] [PubMed]

38. Guarner, F.; Schaafsma, G.J. Probiotics. Int. J. Food Microbiol. 1998, 39, 237-238. [CrossRef]

39. de Melo Pereira, G.V.; de Oliveira Coelho, B.; Magalhães Júnior, A.I.; Thomaz-Soccol, V.; Soccol, C.R. How to select a probiotic? A review and update of methods and criteria. Biotechnol. Adv. 2018, 36, 2060-2076. [CrossRef]

40. Shah, N.P. Probiotic bacteria: Selective enumeration and survival in dairy foods. J. Dairy Sci. 2000, 83, 894-907. [CrossRef]

41. Mantegazza, C.; Molinari, P.; D'Auria, E.; Sonnino, M.; Morelli, L.; Zuccotti, G.V. Probiotics and antibiotic-associated diarrhea in children: A review and new evidence on Lactobacillus rhamnosus GG during and after antibiotic treatment. Pharmacol. Res. 2018, 128, 63-72. [CrossRef] [PubMed]

42. Hojsak, I.; Szajewska, H.; Canani, R.B.; Guarino, A.; Indrio, F.; Kolacek, S.; Orel, R.; Shamir, R.; Vandenplas, Y.; Van Goudoever, J.B.; et al. Probiotics for the prevention of nosocomial diarrhea in children. J. Pediatr. Gastroenterol. Nutr. 2018, 66, 3-9. [CrossRef] [PubMed]

43. Gotova, I.; Dimitrov, Z.; Najdenski, H. Selected lactobacillus bulgaricus and streptococcus thermophilus strains from bulgarian yogurt demonstrate significant anti-inflammatory potential. Acta Microbiol. Bulg. 2017, 33, 137-142.

44. Kostelac, D.; Gerić, M.; Gajski, G.; Markov, K.; Domijan, A.M.; Čanak, I.; Jakopović, Ž.; Svetec, I.K.; Žunar, B.; Frece, J. Lactic acid bacteria isolated from equid milk and their extracellular metabolites show great probiotic properties and anti-inflammatory potential. Int. Dairy J. 2021, 112, 104828. [CrossRef]

45. Maria-Aggeliki, K.S.; Nikolaos, K.L.; Kyrias, G.M.; Vassilis, K.E. The Potential Clinical Impact of Probiotic Treatment for the Prevention and/or Anti-Inflammatory Therapeutic Effect Against Radiation Induced Intestinal Mucositis. A Review. Recent Pat. Inflamm. Allergy Drug Discov. 2009, 3, 195-200. [CrossRef] [PubMed]

46. Rondanelli, M.; Faliva, M.A.; Perna, S.; Giacosa, A.; Peroni, G.; Castellazzi, A.M. Using probiotics in clinical practice: Where are we now? A review of existing meta-analyses. Gut Microbes 2017, 8, 521-543. [CrossRef] [PubMed]

47. Abdellatif, B.; McVeigh, C.; Bendriss, G.; Chaari, A. The Promising Role of Probiotics in Managing the Altered Gut in Autism Spectrum Disorders. Int. J. Mol. Sci. 2020, 21, 4159. [CrossRef] [PubMed] 
48. Cavalcanti Neto, M.P.; de Souza Aquino, J.; Romão da Silva, L.d.F.; de Oliveira Silva, R.; de Lima Guimarães, K.S.; de Oliveira, Y.; de Souza, E.L.; Magnani, M.; Vidal, H.; de Brito Alves, J.L. Gut microbiota and probiotics intervention: A potential therapeutic target for management of cardiometabolic disorders and chronic kidney disease? Pharmacol. Res. 2018, 130, 152-163. [CrossRef] [PubMed]

49. Szántó, M.; Dózsa, A.; Antal, D.; Szabó, K.; Kemény, L.; Bai, P. Targeting the gut-skin axis—Probiotics as new tools for skin disorder management? Exp. Dermatol. 2019, 28, 1210-1218. [CrossRef] [PubMed]

50. Bermúdez-Humarán, L.G.; Salinas, E.; Ortiz, G.G.; Ramirez-Jirano, L.J.; Morales, J.A.; Bitzer-Quintero, O.K. From Probiotics to Psychobiotics: Live Beneficial Bacteria Which Act on the Brain-Gut Axis. Nutrients 2019, 11, 890. [CrossRef] [PubMed]

51. Granato, D.; Branco, G.F.; Cruz, A.G.; Faria, J.d.A.F.; Shah, N.P. Probiotic Dairy Products as Functional Foods. Compr. Rev. Food Sci. Food Saf. 2010, 9, 455-470. [CrossRef]

52. Neffe-Skocińska, K.; Rzepkowska, A.; Szydłowska, A.; Kołożyn-Krajewska, D. Trends and Possibilities of the Use of Probiotics in Food Production. In Handbook of Food Bioengineering; Holban, A.M., Grumezescu, A., Eds.; Academic Press: Cambridge, MA, USA, 2018; pp. 65-94, ISBN 978-0-12-811446-9.

53. Roobab, U.; Batool, Z.; Manzoor, M.F.; Shabbir, M.A.; Khan, M.R.; Aadil, R.M. Sources, formulations, advanced delivery and health benefits of probiotics. Curr. Opin. Food Sci. 2020, 32, 17-28. [CrossRef]

54. Vinderola, C.G.; Mocchiutti, P.; Reinheimer, J.A. Interactions among lactic acid starter and probiotic bacteria used for fermented dairy products. J. Dairy Sci. 2002, 85, 721-729. [CrossRef]

55. Boylston, T.D.; Vinderola, C.G.; Ghoddusi, H.B.; Reinheimer, J.A. Incorporation of bifidobacteria into cheeses: Challenges and rewards. Int. Dairy J. 2004, 14, 375-387. [CrossRef]

56. Kailasapathy, K.; Harmstorf, I.; Phillips, M. Survival of Lactobacillus acidophilus and Bifidobacterium animalis ssp. lactis in stirred fruit yogurts. LWT-Food Sci. Technol. 2008, 41, 1317-1322. [CrossRef]

57. Gursoy, O.; Kinik, O. Incorporation of adjunct cultures of Enterococcus faecium, Lactobacillus paracasei subsp. paracasei and Bifidobacterium bifidum into white cheese. J. Food Agric. Environ. 2010, 8, 107-112.

58. Mohammadi, R.; Mortazavian, A.M.; Khosrokhavar, R.; da Cruz, A.G. Probiotic ice cream: Viability of probiotic bacteria and sensory properties. Ann. Microbiol. 2011, 61, 411-424. [CrossRef]

59. Wilkinson, M.G. Flow cytometry as a potential method of measuring bacterial viability in probiotic products: A review. Trends Food Sci. Technol. 2018, 78, 1-10. [CrossRef]

60. Davey, H.M. Life, death, and in-between: Meanings and methods in microbiology. Appl. Environ. Microbiol. 2011, 77, 5571-5576. [CrossRef] [PubMed]

61. Ebrahimi, B.; Mohammadi, R.; Rouhi, M.; Mortazavian, A.M.; Shojaee-Aliabadi, S.; Koushki, M.R. Survival of probiotic bacteria in carboxymethyl cellulose-based edible film and assessment of quality parameters. LWT 2018, 87, 54-60. [CrossRef]

62. Terpou, A.; Papadaki, A.; Lappa, I.K.; Kachrimanidou, V.; Bosnea, L.A.; Kopsahelis, N. Probiotics in Food Systems: Significance and Emerging Strategies Towards Improved Viability and Delivery of Enhanced Beneficial Value. Nutrients 2019, 11, 1591. [CrossRef]

63. Sadeghi-Varkani, A.; Emam-Djomeh, Z.; Askari, G. Physicochemical and microstructural properties of a novel edible film synthesized from Balangu seed mucilage. Int. J. Biol. Macromol. 2018, 108, 1110-1119. [CrossRef] [PubMed]

64. Burgain, J.; Scher, J.; Francius, G.; Borges, F.; Corgneau, M.; Revol-Junelles, A.M.; Cailliez-Grimal, C.; Gaiani, C. Lactic acid bacteria in dairy food: Surface characterization and interactions with food matrix components. Adv. Colloid Interface Sci. 2014, 213, 21-35. [CrossRef] [PubMed]

65. Ly, M.H.; Covarrubias-Cervantes, M.; Dury-Brun, C.; Bordet, S.; Voilley, A.; Le, T.M.; Belin, J.-M.; Waché, Y. Retention of aroma compounds by lactic acid bacteria in model food media. Food Hydrocoll. 2008, 22, 211-217. [CrossRef]

66. Rodríguez, H.; Curiel, J.A.; Landete, J.M.; de las Rivas, B.; de Felipe, F.L.; Gómez-Cordovés, C.; Mancheño, J.M.; Muñoz, R. Food phenolics and lactic acid bacteria. Int. J. Food Microbiol. 2009, 132, 79-90. [CrossRef] [PubMed]

67. Gibson, G.R.; Hutkins, R.; Sanders, M.E.; Prescott, S.L.; Reimer, R.A.; Salminen, S.J.; Scott, K.; Stanton, C.; Swanson, K.S.; Cani, P.D.; et al. Expert consensus document: The International Scientific Association for Probiotics and Prebiotics (ISAPP) consensus statement on the definition and scope of prebiotics. Nat. Rev. Gastroenterol. Hepatol. 2017, 14, 491-502. [CrossRef] [PubMed]

68. Bagga, D.; Reichert, J.L.; Koschutnig, K.; Aigner, C.S.; Holzer, P.; Koskinen, K.; Moissl-Eichinger, C.; Schöpf, V. Probiotics drive gut microbiome triggering emotional brain signatures. Gut Microbes 2018, 9, 486-496. [CrossRef] [PubMed]

69. Langa, S.; van den Bulck, E.; Peirotén, A.; Gaya, P.; Schols, H.A.; Arqués, J.L. Application of lactobacilli and prebiotic oligosaccharides for the development of a synbiotic semi-hard cheese. LWT 2019, 114, 108361. [CrossRef]

70. Tarrah, A.; de Castilhos, J.; Rossi, R.C.; Duarte, V. da S.; Ziegler, D.R.; Corich, V.; Giacomini, A. In vitro Probiotic Potential and Anti-cancer Activity of Newly Isolated Folate-Producing Streptococcus thermophilus Strains. Front. Microbiol. 2018, 9, 2214 [CrossRef] [PubMed]

71. Bautista-Gallego, J.; Ferrocino, I.; Botta, C.; Ercolini, D.; Cocolin, L.; Rantsiou, K. Probiotic potential of a Lactobacillus rhamnosus cheese isolate and its effect on the fecal microbiota of healthy volunteers. Food Res. Int. 2019, 119, 305-314. [CrossRef] [PubMed]

72. Gibson, G.R.; Probert, H.M.; Van Loo, J.; Rastall, R.A.; Roberfroid, M.B. Dietary modulation of the human colonic microbiota: Updating the concept of prebiotics. Nutr. Res. Rev. 2004, 17, 259-275. [CrossRef] 
73. Meng, C.; Bai, C.; Brown, T.D.; Hood, L.E.; Tian, Q. Human Gut Microbiota and Gastrointestinal Cancer. Genomics. Proteom. Bioinform. 2018, 16, 33-49. [CrossRef] [PubMed]

74. Brown, L.; Caligiuri, S.; Brown, D.; Pierce, G. Clinical trials using functional foods provide unique challenges. J. Funct. Foods 2018, 45, 233-238. [CrossRef]

75. Yu, H.; Liu, W.; Li, D.; Liu, C.; Feng, Z.; Jiang, B. Targeting Delivery System for Lactobacillus Plantarum Based on Functionalized Electrospun Nanofibers. Polymers 2020, 12, 1565. [CrossRef]

76. Marcial-Coba, M.S.; Knøchel, S.; Nielsen, D.S. Low-moisture food matrices as probiotic carriers. FEMS Microbiol. Lett. 2019, 366, fnz006. [CrossRef] [PubMed]

77. Rodrigues, F.J.; Cedran, M.F.; Bicas, J.L.; Sato, H.H. Encapsulated probiotic cells: Relevant techniques, natural sources as encapsulating materials and food applications-A narrative review. Food Res. Int. 2020, 137, 109682. [CrossRef] [PubMed]

78. Deng, L.; Zhang, H. Recent Advances in Probiotics Encapsulation by Electrospinning. ES Food Agrofor. 2020, 2, 3-12. [CrossRef]

79. Anandharamakrishnan, C.; Padma, S. Encapsulation of probiotics by spray drying. In Spray Drying Techniques for Food Ingredient Encapsulation; Wiley \& Sons: Hoboken, NJ, USA, 2015; pp. 101-125.

80. Ray, S.; Raychaudhuri, U.; Chakraborty, R. An overview of encapsulation of active compounds used in food products by drying technology. Food Biosci. 2016, 13, 76-83. [CrossRef]

81. Gul, O.; Atalar, I. Different stress tolerance of spray and freeze dried Lactobacillus casei Shirota microcapsules with different encapsulating agents. Food Sci. Biotechnol. 2019, 28, 807-816. [CrossRef]

82. Chavarri, M.; Maranon, I.; Carmen, M. Encapsulation Technology to Protect Probiotic Bacteria. In Probiotics; Marañón, I., Ed.; InTech: Rijeka, Croatia, 2012.

83. Rajam, R.; Karthik, P.; Parthasarathi, S.; Joseph, G.S.; Anandharamakrishnan, C. Effect of whey protein-Alginate wall systems on survival of microencapsulated Lactobacillus plantarum in simulated gastrointestinal conditions. J. Funct. Foods 2012, 4, 891-898. [CrossRef]

84. Sakai, T.; Moteki, Y.; Takahashi, T.; Shida, K.; Kiwaki, M.; Shimakawa, Y.; Matsui, A.; Chonan, O.; Morikawa, K.; Ohta, T.; et al. Probiotics into outer space: Feasibility assessments of encapsulated freeze-dried probiotics during 1 month's storage on the International Space Station. Sci. Rep. 2018, 8, 10687. [CrossRef] [PubMed]

85. Thomas, M.B.; Vaidyanathan, M.; Radhakrishnan, K.; Raichur, A.M. Enhanced viability of probiotic Saccharomyces boulardii encapsulated by layer-by-layer approach in $\mathrm{pH}$ responsive chitosan-dextran sulfate polyelectrolytes. J. Food Eng. 2014, 136, 1-8. [CrossRef]

86. Krasaekoopt, W.; Bhandari, B. 18-Properties and applications of different probiotic delivery systems. In Woodhead Publishing Series in Food Science, Technology and Nutrition; Garti, N., McClements, D.J., Eds.; Woodhead Publishing: Sawston, UK, 2012; pp. 541-594, ISBN 978-0-85709-124-6.

87. Yao, M.; Li, B.; Ye, H.; Huang, W.; Luo, Q.; Xiao, H.; McClements, D.J.; Li, L. Enhanced viability of probiotics (Pediococcus pentosaceus Li05) by encapsulation in microgels doped with inorganic nanoparticles. Food Hydrocoll. 2018, 83, 246-252. [CrossRef]

88. Massounga Bora, A.F.; Li, X.; Zhu, Y.; Du, L. Improved Viability of Microencapsulated Probiotics in a Freeze-Dried Banana Powder During Storage and Under Simulated Gastrointestinal Tract. Probiotics Antimicrob. Proteins 2019, 11, 1330-1339. [CrossRef] [PubMed]

89. Heidebach, T.; Först, P.; Kulozik, U. Influence of casein-based microencapsulation on freeze-drying and storage of probiotic cells. J. Food Eng. 2010, 98, 309-316. [CrossRef]

90. Moayyedi, M.; Eskandari, M.H.; Rad, A.H.E.; Ziaee, E.; Khodaparast, M.H.H.; Golmakani, M.T. Effect of drying methods (electrospraying, freeze drying and spray drying) on survival and viability of microencapsulated Lactobacillus rhamnosus ATCC 7469. J. Funct. Foods 2018, 40, 391-399. [CrossRef]

91. Patarroyo, J.L.; Florez-Rojas, J.; Pradilla, D.; Valderrama-Rincon, J.; Cruz, J.; Reyes, L. Formulation and Characterization of Gelatin-Based Hydrogels for the Encapsulation of Kluyveromyces lactis-Applications in Packed-Bed Reactors and Probiotics Delivery in Humans. Polymers 2020, 12, 1287. [CrossRef] [PubMed]

92. Vishali, D.A.; Monisha, J.; Sivakamasundari, S.K.; Moses, J.A.; Anandharamakrishnan, C. Spray freeze drying: Emerging applications in drug delivery. J. Control. Release 2019, 300, 93-101. [CrossRef] [PubMed]

93. Eckert, C.; Agnol, W.; Dallé, D.; Serpa, V.; Jachetti Maciel, M.; Lehn, D.; Souza, C. Development of alginate-pectin microparticles with dairy whey using vibration technology: Effects of matrix composition on the protection of Lactobacillus spp. from adverse conditions. Food Res. Int. 2018, 113, 65-73. [CrossRef] [PubMed]

94. Burgain, J.; Gaiani, C.; Linder, M.; Scher, J. Encapsulation of probiotic living cells: From laboratory scale to industrial applications. J. Food Eng. 2011, 104, 467-483. [CrossRef]

95. Poletto, G.; Raddatz, G.; Cichoski, A.; Zepka, L.; Jacob-Lopes, E.; Barin, J.; Wagner, R.; Menezes, C. Study of viability and storage stability of Lactobacillus acidophillus when encapsulated with the prebiotics rice bran, inulin and Hi-maize. Food Hydrocoll. 2019, 95, 238-244. [CrossRef]

96. Gul, O.; Dervisoglu, M. Application of multicriteria decision technique to determine optimum sodium alginate concentration for microencapsulation of Lactobacillus casei Shirota by extrusion and emulsification. J. Food Process Eng. 2017, 40, e12481. [CrossRef]

97. Qi, W.; Liang, X.; Yun, T.; Guo, W. Growth and survival of microencapsulated probiotics prepared by emulsion and internal gelation. J. Food Sci. Technol. 2019, 56, 1398-1404. [CrossRef] [PubMed] 
98. Gbassi, G.K.; Vandamme, T. Probiotic encapsulation technology: From microencapsulation to release into the gut. Pharmaceutics 2012, 4, 149-163. [CrossRef] [PubMed]

99. de Almeida Paula, D.; Martins, E.M.F.; de Almeida Costa, N.; de Oliveira, P.M.; de Oliveira, E.B.; Ramos, A.M. Use of gelatin and gum arabic for microencapsulation of probiotic cells from Lactobacillus plantarum by a dual process combining double emulsification followed by complex coacervation. Int. J. Biol. Macromol. 2019, 133, 722-731. [CrossRef]

100. Holkem, A.T.; Raddatz, G.C.; Nunes, G.L.; Cichoski, A.J.; Jacob-Lopes, E.; Ferreira Grosso, C.R.; de Menezes, C.R. Development and characterization of alginate microcapsules containing Bifidobacterium BB-12 produced by emulsification/internal gelation followed by freeze drying. LWT-Food Sci. Technol. 2016, 71, 302-308. [CrossRef]

101. McClements, D.J. Protein-stabilized emulsions. Curr. Opin. Colloid Interface Sci. 2004, 9, 305-313. [CrossRef]

102. Lotfipour, F.; Mirzaeei, S.; Maghsoodi, M. Evaluation of the effect of $\mathrm{CaCl} 2$ and alginate concentrations and hardening time on the characteristics of Lactobacillus acidophilus loaded alginate beads using response surface analysis. Adv. Pharm. Bull. 2012, 2, 71-78. [CrossRef]

103. Rajam, R.; Anandharamakrishnan, C. Spray freeze drying method for microencapsulation of Lactobacillus plantarum. J. Food Eng. 2015, 166, 95-103. [CrossRef]

104. Semyonov, D.; Ramon, O.; Kaplun, Z.; Levin-Brener, L.; Gurevich, N.; Shimoni, E. Microencapsulation of Lactobacillus paracasei by spray freeze drying. Food Res. Int. 2010, 43, 193-202. [CrossRef]

105. Levine, H.; Slade, L. Another view of trehalose for drying and stabilizing biological materials. BioPharm 1992, 5, 36-40.

106. Solanki, H.K.; Pawar, D.D.; Shah, D.A.; Prajapati, V.D.; Jani, G.K.; Mulla, A.M.; Thakar, P.M. Development of microencapsulation delivery system for long-term preservation of probiotics as biotherapeutics agent. BioMed Res. Int. 2013, 2013, 620719. [CrossRef]

107. Yoha, K.S.; Moses, J.A.; Anandharamakrishnan, C. Effect of encapsulation methods on the physicochemical properties and the stability of Lactobacillus plantarum (NCIM 2083) in synbiotic powders and in-vitro digestion conditions. J. Food Eng. 2020, 283, 110033. [CrossRef]

108. Yoha, K.S.; Moses, J.A.; Anandharamakrishnan, C. Conductive hydro drying through refractance window drying-An alternative technique for drying of Lactobacillus plantarum (NCIM 2083). Dry Technol. 2020, 38, 610-620. [CrossRef]

109. Raghavi, L.M.; Moses, J.A.; Anandharamakrishnan, C. Refractance window drying of foods: A review. J. Food Eng. 2018, 222, 267-275. [CrossRef]

110. Bernaert, N.; Van Droogenbroeck, B.; Van Pamel, E.; De Ruyck, H. Innovative refractance window drying technology to keep nutrient value during processing. Trends Food Sci. Technol. 2019, 84, 22-24. [CrossRef]

111. Amna, T.; Hassan, M.S.; Pandeya, D.R.; Khil, M.-S.; Hwang, I.H. Classy non-wovens based on animate L. gasseri-inanimate poly(vinyl alcohol): Upstream application in food engineering. Appl. Microbiol. Biotechnol. 2013, 97, 4523-4531. [CrossRef] [PubMed]

112. Jacobsen, C.; García-Moreno, P.J.; Mendes, A.C.; Mateiu, R.V.; Chronakis, I.S. Use of Electrohydrodynamic Processing for Encapsulation of Sensitive Bioactive Compounds and Applications in Food. Annu. Rev. Food Sci. Technol. 2018, 9, 525-549. [CrossRef] [PubMed]

113. López-Rubio, A.; Sanchez, E.; Wilkanowicz, S.; Sanz, Y.; Lagaron, J.M. Electrospinning as a useful technique for the encapsulation of living bifidobacteria in food hydrocolloids. Food Hydrocoll. 2012, 28, 159-167. [CrossRef]

114. Anu Bhushani, J.; Anandharamakrishnan, C. Electrospinning and electrospraying techniques: Potential food based applications. Trends Food Sci. Technol. 2014, 38, 21-33. [CrossRef]

115. Zhang, L.; Lou, Y.; Schutyser, M.A.I. 3D printing of cereal-based food structures containing probiotics. Food Struct. 2018, 18, 14-22. [CrossRef]

116. Yoha, K.S.; Anukiruthika, T.; Anila, W.; Moses, J.A.; Anandharamakrishnan, C. 3D printing of encapsulated probiotics: Effect of different post-processing methods on the stability of Lactiplantibacillus plantarum (NCIM 2083) under static in vitro digestion conditions and during storage. LWT 2021, 146, 111461. [CrossRef]

117. Chen, J.; Vestergaard, M.; Shen, J.; Solem, C.; Dufva, M.; Jensen, P. Droplet-based microfluidics as a future tool for strain improvement in lactic acid bacteria. FEMS Microbiol. Lett. 2018, 365, fny258. [CrossRef] [PubMed]

118. Villa, M.; Bloom, R.; Silverman, J.; Durand, H.; Jiang, S.; Wu, A.; Huang, S.; You, L.; David, L. High-Throughput Isolation and Culture of Human Gut Bacteria with Droplet Microfluidics. 2019. Available online: https:/ /www.semanticscholar.org/paper/ High-throughput-isolation-and-culture-of-human-gut-Villa-Bloom/7d750443ffa753680b11d8980d7ea5fd92e93a50 (accessed on 12 October 2021). 